\title{
Research on Hydraulic Fracturing Pressure Relief Technology in the Deep High-Stress Roadway for Surrounding Rock Control
}

\author{
Wen Zhai, ${ }^{1,2}$ Yachao Guo $\mathbb{D}^{1},{ }^{1}$ Xiaochuan Ma ${ }^{D},{ }^{3}$ Nailv Li, ${ }^{4,5}$ Peng Zhang, ${ }^{1}$ Kun Ma, ${ }^{1,2}$ \\ Yuanxin Jing, ${ }^{1}$ Hong $\mathrm{Yu}^{1}{ }^{1}$ and Xiaotong $\mathrm{Li}^{1}$ \\ ${ }^{1}$ State Key Laboratory of Coal Resources and Safe Mining, School of Mines, China University of Mining and Technology, \\ Xuzhou 221116, China \\ ${ }^{2}$ National Energy Group Ningxia Coal Industry Co., Ltd., Yinchuan 750000, China \\ ${ }^{3}$ Xinjiang Institute of Engineering, Urumqi, Xinjiang 830023, China \\ ${ }^{4}$ Shandong Energy Xinwen Mining Group Co., Ltd., Xintai, Shandong 271200, China \\ ${ }^{5}$ Binxian Shuiliandong Coal Mine Co., Ltd., Binzhou, Shanxi 713500, China
}

Correspondence should be addressed to Yachao Guo; yachaoguo2020@163.com and Xiaochuan Ma; chuan1682006@126.com

Received 5 May 2021; Revised 17 August 2021; Accepted 7 October 2021; Published 25 October 2021

Academic Editor: Jian Xu

Copyright (c) 2021 Wen Zhai et al. This is an open access article distributed under the Creative Commons Attribution License, which permits unrestricted use, distribution, and reproduction in any medium, provided the original work is properly cited.

With the increase of mining depth in underground engineering, deep ground pressure has an extremely unfavorable impact on safety production and the economic benefits of coal mines and the control of the roadway stability in deep mines are gradually highlighted. In this study, the working face 14203 of the Zaoquan coal mine was taken as the engineering background, the deformation mechanism of surrounding rock in the deep-buried high-stress roadway was analyzed, and the hydraulic fracturing pressure relief technology in the advanced roadway was proposed for surrounding rock control. Finally, the numerical simulation and field tests were used to validate the comprehensive effect of the proposed technology. Without damaging the roadway stability in the working face, the hydraulic fracturing pressure relief technology can optimize the stress environment and stability of the roadway through the artificial control of the roof fracture position. The numerical simulation shows that under the action of hydraulic fracturing, the cutting slot is formed, the deformation and failure mode of the roof are changed, the stress of surrounding rock is reduced, and the development of the plastic zone of surrounding rock is limited. As a result, the stability of surrounding rock in the roadway is effectively protected. The field test shows that after the adoption of hydraulic fracturing pressure relief technology, the roof subsidence, floor separation, bolt stress, and cable stress decrease, and the deformation of surrounding rock is reduced significantly. Therefore, hydraulic fracturing pressure relief technology is verified as an effective method to control the large deformation of the surrounding rock in the deep-buried roadway.

\section{Introduction}

In recent years, the mining depth and mining scope have been continuously increased. Compared with the shallow mining, the geological process characteristics and mine pressure behavior law under the condition of deep mining have been changed greatly: for the deep mine, the vertical stress (caused by the gravity) and the in situ stress are higher, and the tectonic stress field is more complex. Deep ground pressure has an extremely unfavorable impact on safety production and economic benefits of coal mines [1-3]. In the deep mining, the deformation characteristics of coal rock are changed from brittleness to plasticity, and the dilatancy and the impact risk of coal rock are increased. In the deep roadway, complex geological conditions and high ground stress fields often cause serious deformation and failure of surrounding rock $[4,5]$. Therefore, the deformation and failure of surrounding rock should be effectively controlled under the strong mine pressure in deep mining to ensure safe mining.

Research on the deformation mechanism and stability of surrounding rock of deep high-stress roadway has been widely performed. Zhang [6] studied the loose blasting and 
pressure release channel of surrounding rock through the FLAC numerical simulation software. To solve the problem of roadway deformation in short cantilever beam roof excavation theory, Yang et al. [7] proposed the roof excavation pressure relief method in the adjacent roadway and determined the presplit blasting technical parameters through theoretical analysis. Yang et al. [8] studied the stress process of bolt on the roof by three-dimensional numerical simulation, analyzed the time effect of bolt mechanical properties, and summarized the working mechanism of floor bolt. $\mathrm{He}$ et al. $[9,10]$ pointed out that in the deep coal mining, the rock mass medium is in the stage of large plastic deformation, leading to more significant nonlinear mechanical phenomena; as for the supporting technology, the coupling of the strength, stiffness, and structure between the support body and the surrounding rock should be considered. Zuo et al. [11] systematically analyzed the macro/meso failure mechanism of deep rock or coal rock combinations under different loading conditions. The stress gradient failure theory of surrounding rock, the hyperbolic movement model of uniform support in the deep roadway, and overburden simulation were established, and the combined grouting control technology of surface and underground was proposed. In addition, Xiao et al. [12-16] studied the failure mechanism and control measures of soft rock in the deep roadway.

In previous studies, hard roof collapse behind the working face has been mainly investigated, while the study on stability control of deep roadway has been rarely reported. The working face 14203 in the Zaoquan coal mine was a typical deep mining face with a large mining height. Under the joint influence of large buried depth, high stress, and advanced mining, large deformation occurred in the roadway. According to the stress environment of the roadway, on the premise of not affecting the production of the working face and the integrity of the presplit roadway roof, the hydraulic fracturing pressure relief technology for surrounding rock control was performed in the advanced roadway of the working face. Besides, theoretical analysis, numerical simulation, and field tests were employed to study the mechanism of the hydraulic fracturing pressure relief technology and its implementation effect. The research results can provide a reference for roadway stability control under similar conditions.

\section{Engineering Background}

2.1. Production and Geological Conditions. Zaoquan coal mine was located at the edge of Maowusu Desert, which was $62 \mathrm{~km}$ southeast of the Lingwu City, Ningxia Hui Autonomous Region. Its geographical coordinates were $106^{\circ} 30^{\prime}$ $106^{\circ} 35^{\prime} \mathrm{E}$ and $37^{\circ} 52^{\prime}-38^{\circ} 02^{\prime} \mathrm{N}$. The coal seam 2 of the working face 14203 was the main fully mechanized working face with a large mining height. The thickness of coal seam 2 was $8.07-8.39 \mathrm{~m}$, the dip angle was $2^{\circ}-13^{\circ}$, the strike length was $2336 \mathrm{~m}$, and the dip length was $182.82-235 \mathrm{~m}$. The direct roof was composed of siltstone, mudstone, and carbonaceous mudstone, with an average thickness of $10.90 \mathrm{~m}$; the main roof was composed of medium-grained sandstone and fine-grained sandstone and siltstone, with an average thickness of $35.45 \mathrm{~m}$. The floor was composed of mudstone, siltstone, and fine-grained sandstone, with an average thickness of $5.64 \mathrm{~m}$. The east side of the working face was the excavated area, the south side was the F69 normal fault of No. 13 and No. 14 mining areas, the west side was the old goaf of the working face 14202. Between the working face 14203 and the goaf, there was a coal pillar of $14 \mathrm{~m}$. The north side was the $2^{\text {nd }}$ and $3^{\text {rd }}$ middle yard of No. 14 mining area, and there was no goaf in the upper part of the working face. The buried depth of the rubber-tire haulage gateway in the fully mechanized working face 14203 was about $660 \mathrm{~m}$, and the buried depth of the return airway was about $627 \mathrm{~m}$. The cross section sizes of the rubber-tire haulage gateway and the return airway of the working face 14203 were $4500 \mathrm{~mm} \times 3550 \mathrm{~mm}$ with the joint support of anchor, mesh, and cable, as shown in Figure 1.

\subsection{Analysis of Deformation Characteristics of the Test Roadway}

2.2.1. Deformation Characteristics of the Test Roadway. Due to the joint influence of the large buried depth, high ground stress, and advanced mining of the working face, the roof subsidence, floor heave, and serious shrinkage of two sides appeared in the rubber-tire haulage gateway and return airway. The roadway deformation within 30 meters ahead of the working face was still severe (serious roof subsidence, floor heave, and side shrinkage), the erected steel beam shed was compressed and fractured, and the single hydraulic prop was bent. As shown in Figure 2, the roof sank and pressed on the transfer machine section, and the transfer machine and end support were unable to move normally, which seriously affected the safety production of the working face.

2.2.2. Cause Analysis of Roadway Deformation. The complex structures such as large faults and collapse columns have not been exposed during the excavation process of the rubbertire haulage gateway in the working face 14203 . However, due to its large buried depth $(660 \mathrm{~m})$, the in situ stress environment had an important impact on the roadway deformation. In the field, the SYY-56 Small Aperture Hydraulic Fracturing In Situ Stress Measurement System produced by Xi'an Zhongzhou Geotechnical Technology Co., Ltd., was used, and measurement stations at four typical positions of working faces 14203 and 14201 were set to measure the in situ stress near the roadway. As shown in Figure 1, the fracture pressure $(\mathrm{Pb})$, fracture tension pressure $(\mathrm{Pr})$, instantaneous closing pressure of hydraulic fracture surface $(\mathrm{Ps})$, and in situ tensile strength $(\mathrm{T})$ of rock in each measuring section were determined. According to the relevant formulas, the main stress value is shown in Table 1.

As shown in Table 1, there was large stress at the measuring points in the test area, and the value of vertical principal stress increases gradually with the increase of the buried depth. The underground in situ stress field type was $\sigma_{v}>\sigma_{H}>\sigma_{h}$ stress field, and the four measuring points were NNE direction. In a word, ground stress was an important 


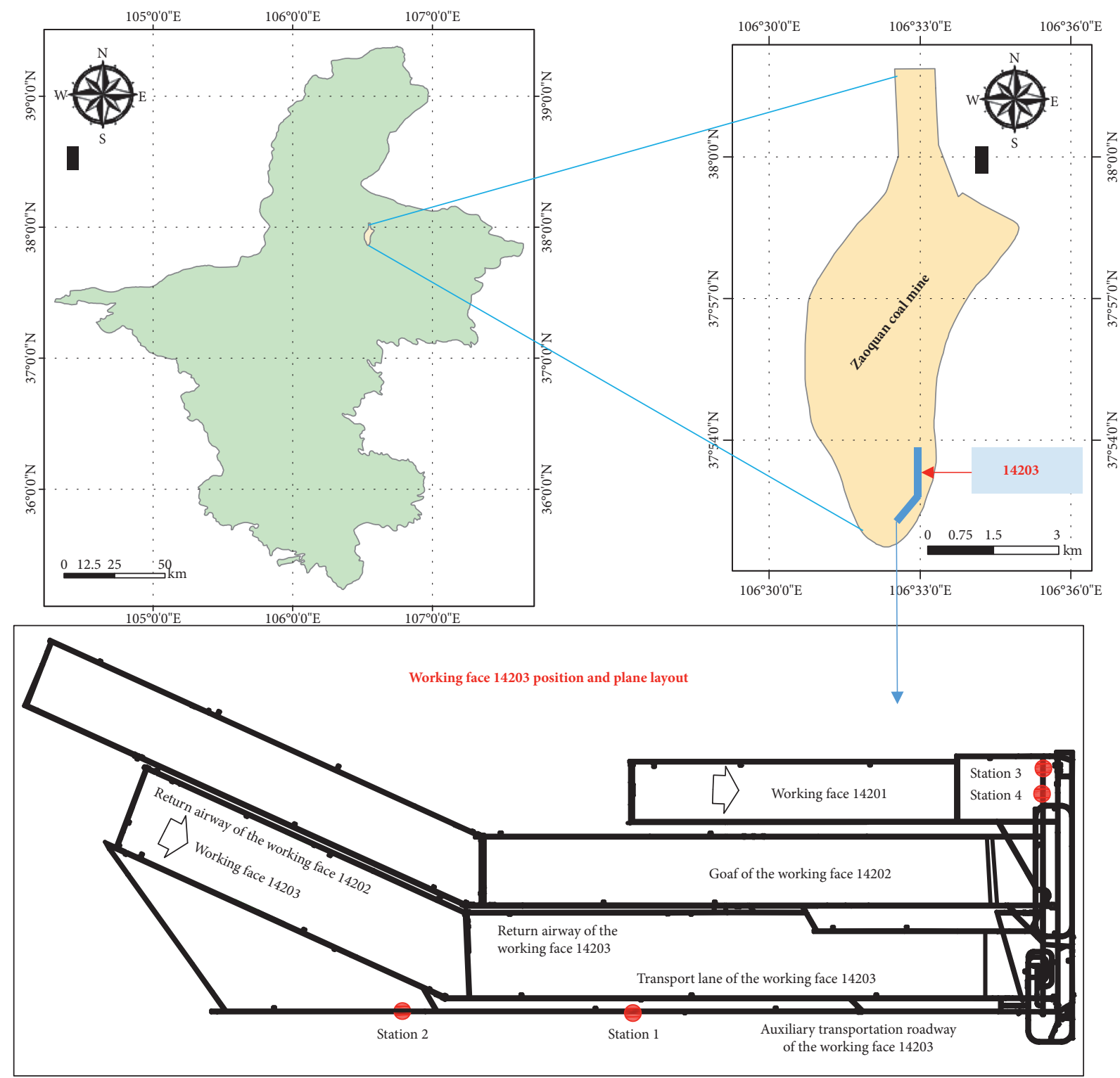

Figure 1: Position and plane layout of the working face 14203.
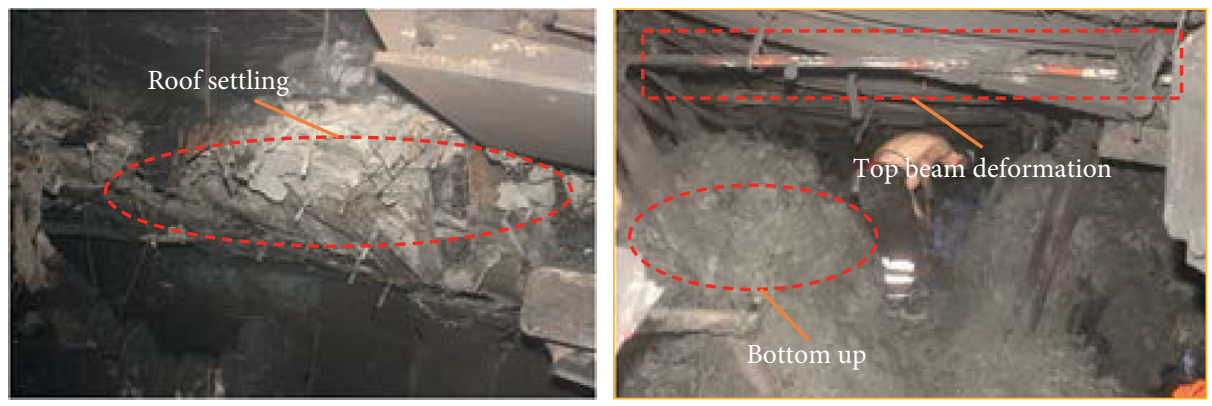

Figure 2: Deformation of two roadways in the working face 14203.

factor causing serious deformation of the roadway. At the same time, the average thickness of the main coal seam in the working face 14203 was $8.2 \mathrm{~m}$, belonging to the large mining-height working face. Compared with the thin coal seam mining, the overburden movement in the goaf of the working face with the large mining height was more intense 
TABLE 1: In situ stress measurement results of hydraulic fracturing in Zaoquan coal mine.

\begin{tabular}{lcccccccccc}
\hline $\begin{array}{l}\text { Measuring point } \\
\text { no. }\end{array}$ & $\begin{array}{c}\text { Buried depth } \\
(\mathrm{m})\end{array}$ & \multicolumn{3}{c}{$\begin{array}{c}\text { Fracturing } \\
\text { parameters }\end{array}$} & \multicolumn{4}{c}{$\begin{array}{c}\text { Principal stress } \\
(\mathrm{MPa})\end{array}$} & $\begin{array}{c}\text { Fracture direction } \\
\left({ }^{\circ}\right)\end{array}$ & $\begin{array}{c}\text { Saturated uniaxial compressive strength } \\
(\mathrm{MPa})\end{array}$ \\
\hline 1 & & $P_{b}$ & $P_{r}$ & $P_{s}$ & $\sigma_{H}$ & $\sigma_{h}$ & $\sigma_{v}$ & & 14.18 \\
2 & 608.8 & 5.44 & 5.03 & 3.99 & 6.52 & 3.78 & 15.22 & $\mathrm{~N} 15.2^{\circ} \mathrm{E}$ & 12.93 \\
3 & 658.1 & 17.30 & 10.28 & 9.00 & 16.30 & 8.79 & 16.45 & $\mathrm{~N} 23.2^{\circ} \mathrm{E}$ & 28.75 \\
4 & 525.4 & 11.74 & 7.47 & 6.13 & 10.49 & 5.91 & 13.14 & $\mathrm{~N} 15.5^{\circ} \mathrm{E}$ & 29.64 \\
\hline
\end{tabular}

after mining. As a result, the rubber-tire haulage gateway was disturbed, and the roadway deformation was inevitably caused.

\section{Roof Hydraulic Fracturing Pressure Relief for Surrounding Rock Control}

3.1. Mechanism of Roof Hydraulic Fracturing Pressure Relief and Roadway Protection. To ensure the normal connection of the working face, the roadway of the next working face is often excavated in advance. When the current working face is mined, the coal pillar between the adjacent working faces will become the stress concentration area, and the roadway serving the next working face will be in a stress concentration environment. As a result, serious roadway deformation is caused, especially in the condition of large buried depth. In this study, the roof hydraulic fracturing pressure relief technology was performed as follows: before the mining of the working face with a large mining height, a special slotting bit was used to prefabricate a transverse slot in the roof drilling; then, the transverse slot section was sealed. The high-pressure water was used to produce cracks at the end of the slot and expand along with the rock layer, and then a "quasifracture surface" was formed in the overburden strata of the roadway pillar. During the mining of the working face, under the action of periodic pressure of stope, the roof of goaf broke along the "quasifracture surface; " the span of cantilever beam was reduced, the action time of lateral abutment pressure was shortened, the stress transmitted by the lateral cantilever beam to the coal pillar of roadway protection was unloaded or transferred, and then the stress state of roadway retaining was improved [17-21]. Finally, the difficulty of roadway maintenance was reduced and the safe production of mine was ensured, as shown in Figure 3.

\subsection{Numerical Simulation of Hydraulic Fracturing Pressure Relief in the Roof and Roadway Protection}

3.2.1. Numerical Calculation Model and Schemes. Based on the geological data of the mine, a numerical calculation model was established by the FLAC6.0 software. The size of the model was $250 \mathrm{~m}$ in length, $100 \mathrm{~m}$ in width, and $80 \mathrm{~m}$ in height, with a total of 2,000,000 grids. The interface unit was used to establish 11 structural planes. A total of 12 strata were simulated from the fine sandstone of the basic floor to the topsoil, as shown in Figure 4. Table 2 shows the mechanical parameters of rock mass.
According to the Mohr-Coulomb criterion, the maximum unbalance force of the model was monitored during the calculation process. When the equilibrium state was obtained in the model, the simulated vertical stress level was $16 \mathrm{MPa}$, and the horizontal stress level was $12 \mathrm{MPa}$. The simulated calculation level was kept at the same level as the monitored in situ stress, as shown in Figure 5. To compare the influence of hydraulic fracturing on the stability of surrounding rock in the roadway, two models were designed for comparative analysis according to the design scheme of hydraulic fracturing drilling parameters .

Scheme 1: the influence of nonhydraulic fracturing in the roof on the stability of rubber-tire haulage gateway 14203 was simulated. According to the data provided by the mining enterprise, the goaf, the return airway, the working face 14203, the rubber-tire haulage gateway, and the auxiliary haulage gateway were excavated in coal seam 2. To meet the needs of numerical simulation calculation, the goaf was reserved for $15 \mathrm{~m}$; the size of return airway, rubber haulage gateway, and auxiliary haulage gateway was $4.5 \mathrm{~m} \times 3.55 \mathrm{~m}$; the distance between the roadway and the coal pillar of $20 \mathrm{~m}$ was reserved in the goaf; and the maximum boundary limit of the working face was reserved for $130 \mathrm{~m}$ as shown in Figure 6(a).

Scheme 2: the influence of roof hydraulic fracturing on the stability of rubber-tire haulage gateway 14203 was simulated. According to the relevant theoretical analysis, the Interface command was used to generate a crack at $45^{\circ}$ along the side face of the rubber-tire haulage gateway, and the length of the crack was $50 \mathrm{~m}$. The other crack was distributed at $5^{\circ}$ along the coal pillar, and the length of the crack was $50 \mathrm{~m}$ as shown in Figure 6(b). After the working face 14203 advanced $20 \mathrm{~m}$ in the working face 14203 , the stress distribution and deformation characteristics of the surrounding rock of the roadway were analyzed and compared in the two schemes.

\subsubsection{Simulation Results}

(1) Influence of Hydraulic Fracturing Pressure Relief on the Stress of the Surrounding Rock. Figure 7 shows the vertical stress distribution nephogram of the two schemes. As shown in Figure 7(a), when roof hydraulic fracturing of rubber-tire haulage gateway is not performed, the low-stress (less than $6 \mathrm{MPa}$ ) areas are mainly concentrated in the position of $20 \mathrm{~m}$ above and below the goaf and $5-8 \mathrm{~m}$ above and below the excavated roadway. These areas are prone to tensile failure. 


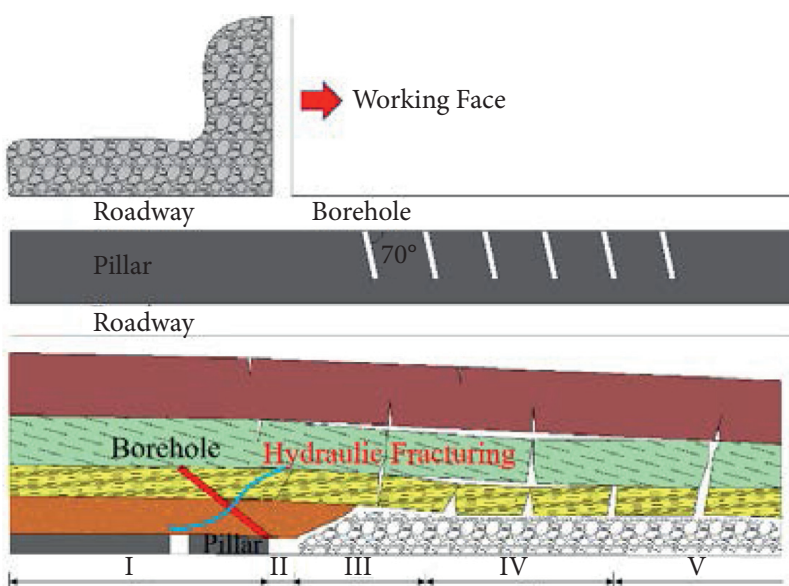

(a)

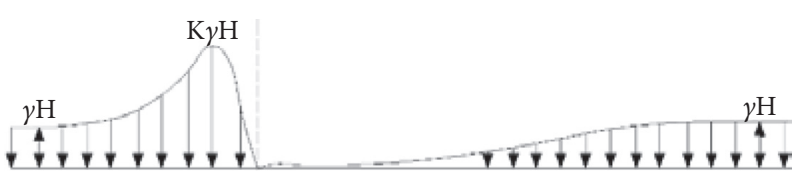

Before hydraulic fracturing

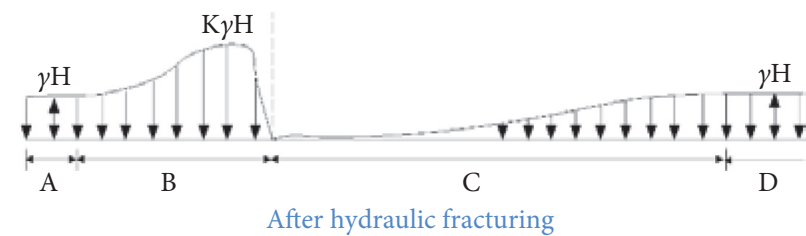

(b)

FIgURE 3: (a) Mechanism of roof hydraulic fracturing pressure relief technology. (b) Stress distribution before and after relief.

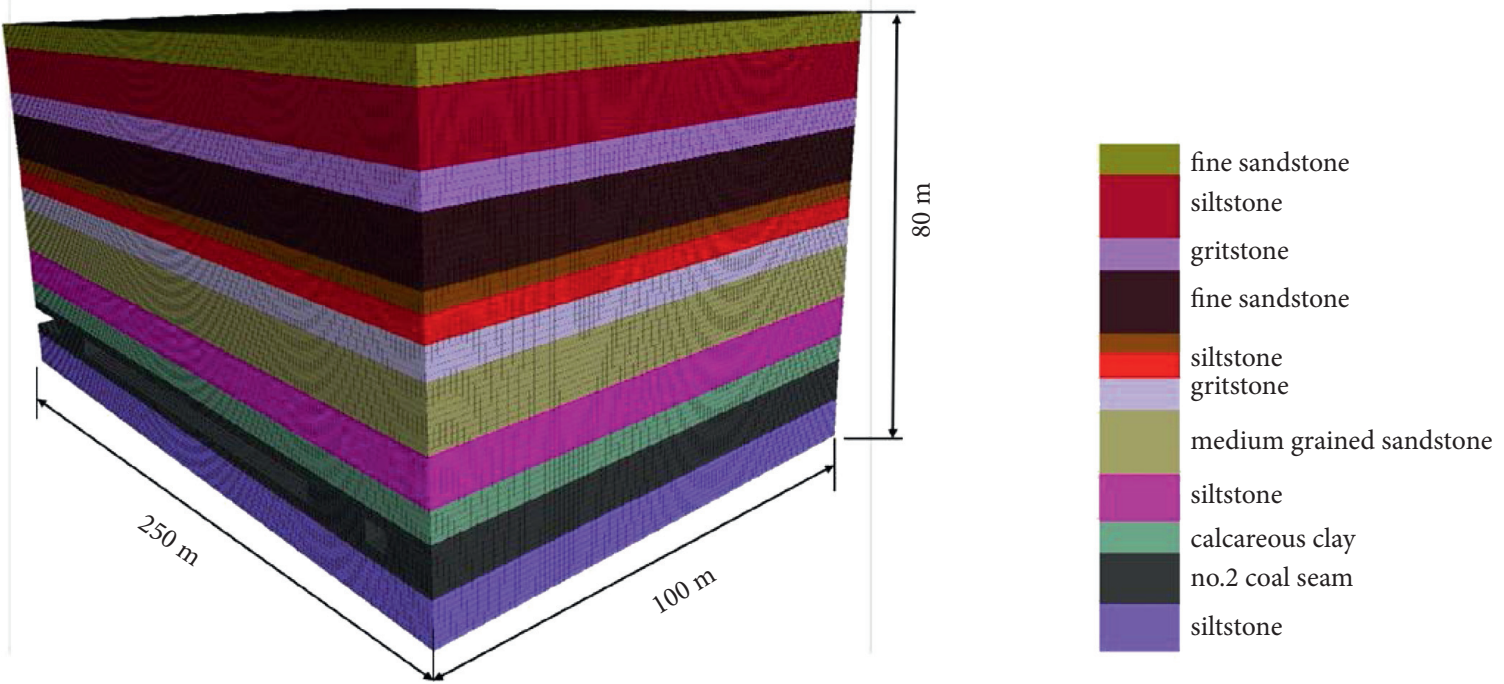

FIgURE 4: Numerical calculation model.

TABLE 2: Some rock mechanics parameters of the numerical model.

\begin{tabular}{|c|c|c|c|c|c|}
\hline Strata & Bulk modulus (K/GPa) & Shear modulus (K/GPa) & Cohesion $(\mathrm{C} / \mathrm{MPa})$ & $\begin{array}{c}\text { Internal friction } \\
\text { angle }\left(\varphi /^{\circ}\right)\end{array}$ & $\begin{array}{c}\text { Density } \\
\left(\rho / \mathrm{kg} / \mathrm{m}^{3}\right)\end{array}$ \\
\hline Coarse-grained sandstone & 3.5 & 1.5 & 2.31 & 32 & 2680 \\
\hline Medium-grained sandstone & 4.2 & 2.1 & 2.9 & 37 & 2670 \\
\hline Siltstone & 4.0 & 1.9 & 3.2 & 38 & 2670 \\
\hline Carbonaceous mudstone & 3.6 & 2.0 & 2.8 & 36 & 2680 \\
\hline 2\# coal seam & 2.5 & 1.2 & 1.56 & 30 & 1380 \\
\hline Siltstone & 4.0 & 1.9 & 3.2 & 38 & 2670 \\
\hline
\end{tabular}

The relatively high-stress (above $11 \mathrm{MPa}$ ) areas are mainly concentrated in the upper $30 \mathrm{~m}$ of the model, and the concentrated stress of the $20 \mathrm{~m}$ coal pillar is even as high as $20 \mathrm{MPa}$. As shown in Figure $7(\mathrm{~b})$, due to the existence of cutting slot after the roof hydraulic fracturing, the low-stress (less than $6 \mathrm{MPa}$ ) area increases significantly, mainly concentrated in the excavation roadway and the upper $50 \mathrm{~m}$ range of goaf. At the same time, the stress between $20 \mathrm{~m}$ coal pillars decreases from the original $20 \mathrm{MPa}$ above to 12-15 MPa, decreasing by about $40 \%$. The relatively highstress $(16 \mathrm{MPa})$ areas are mainly concentrated in the upper $10 \mathrm{~m}$ of the model. On the whole, after hydraulic fracturing, the area of high-stress concentration above the rubber-tire haulage gateway and in the direction of the coal pillar is 


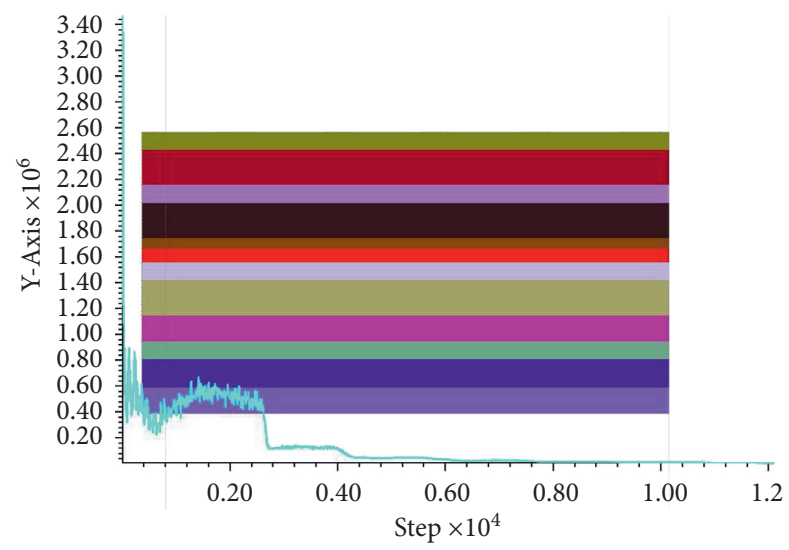

FIgURE 5: Numerical calculation model in the equilibrium state.
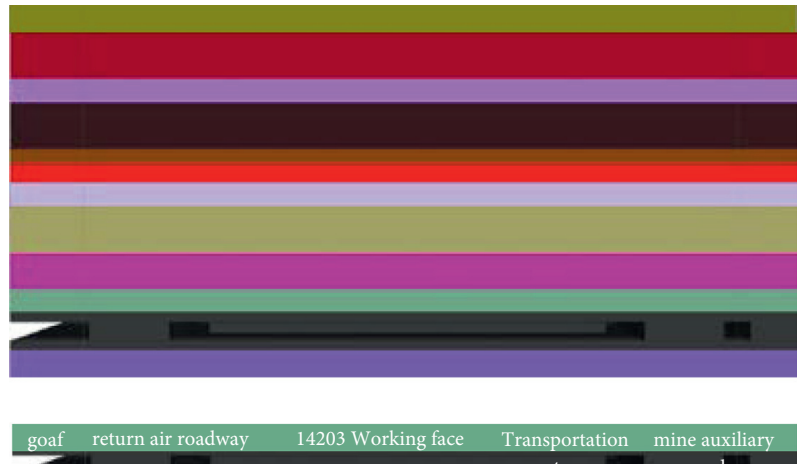

(a)
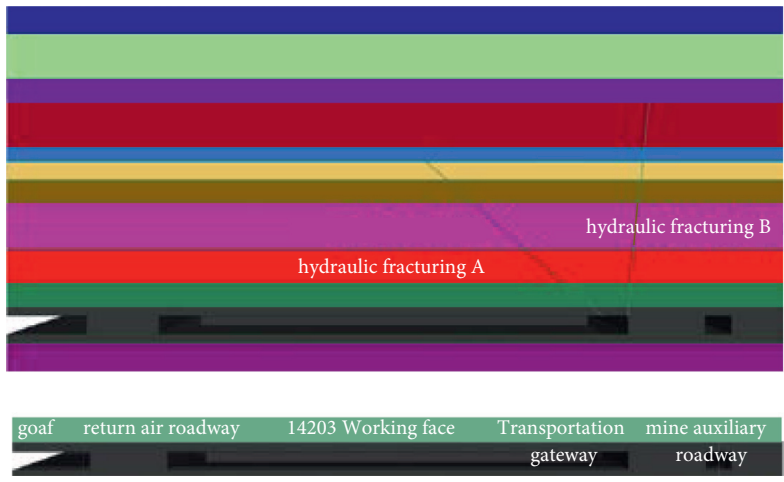

(b)

FIgURE 6: Excavation space relationship diagram of the model. (a) Nonhydraulic fracturing. (b) Hydraulic fracturing.

Zone ZZ Stress Calculated by: Volume

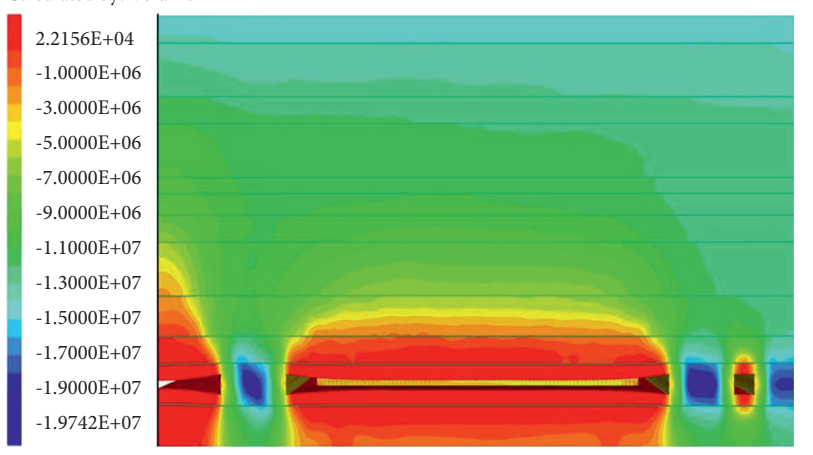

(a)

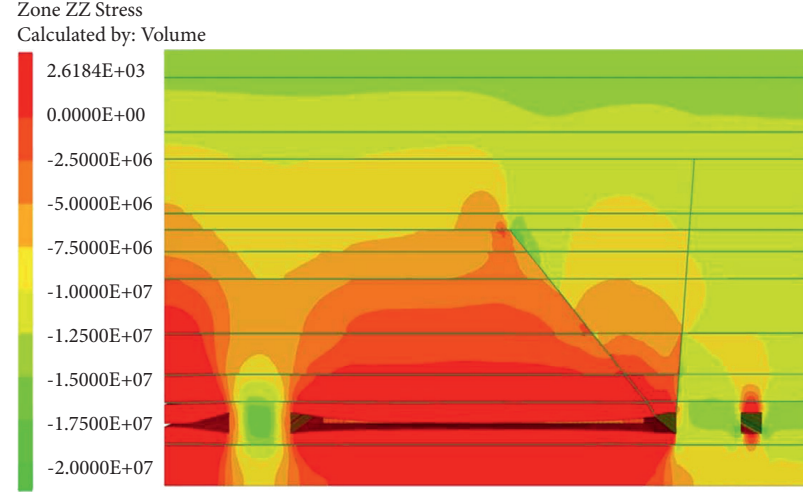

(b)

FIGURE 7: Nephogram of vertical stress of roadway surrounding rock (a) before and (b) after hydraulic fracturing.

obviously reduced. As a result, the damage degree of the area is greatly reduced, and the stability of the roadway is significantly enhanced.

(2) Influence of Hydraulic Fracturing Pressure Relief on the Plastic Zone of Surrounding Rock. Figure 8 shows the change of plastic zone of surrounding rock in the roadway before and after hydraulic fracturing pressure relief. As shown in Figure $8(\mathrm{a})$, the roof subsidence in the nonhydraulic fracturing section is not sufficient, and the plastic zone is about $15 \mathrm{~m}$ in the upper part. The plastic zone of coal pillar is fully developed on the side of the rubber-tire haulage gateway, and there is a range of $2-5 \mathrm{~m}$ free of plastic failure in the middle of the $20 \mathrm{~m}$ coal pillar. The development range of the 

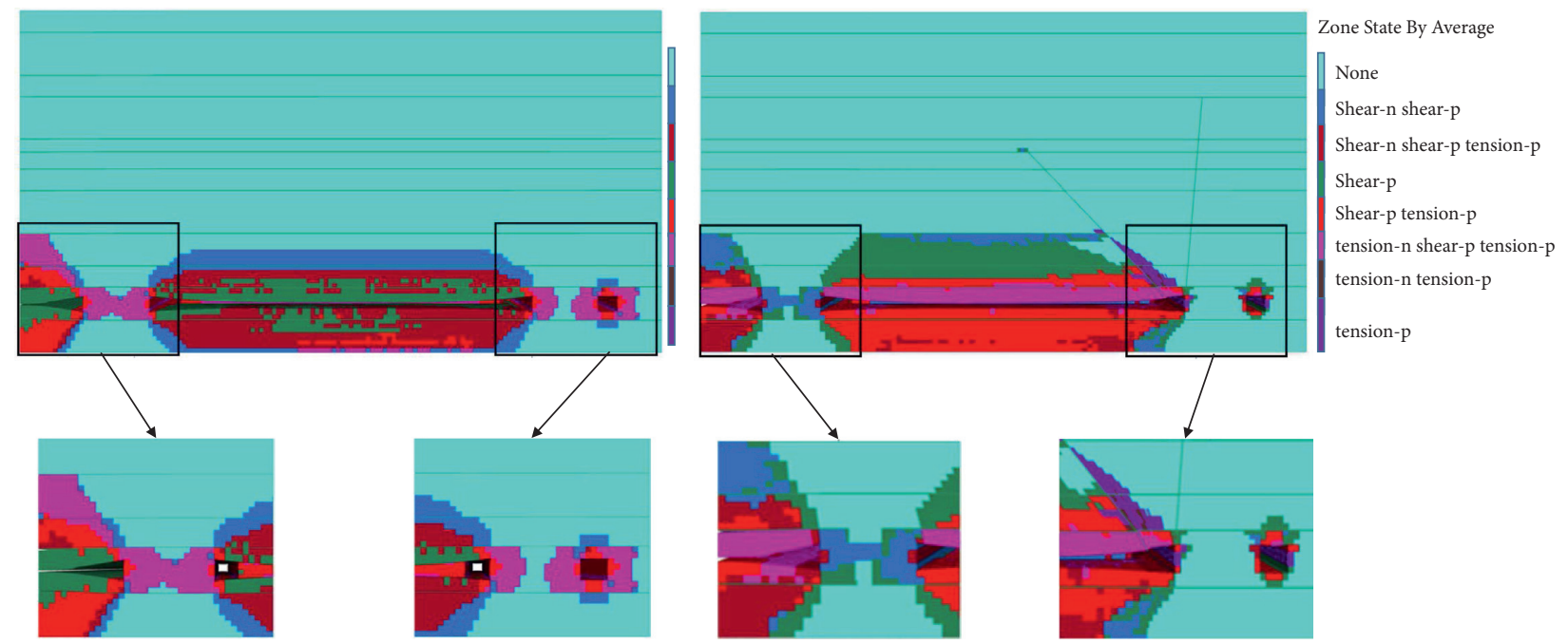

FIGURE 8: Variation cloud map of plastic zone of surrounding rock in the roadway (a) before and (b) after hydraulic fracturing.

plastic zone in the upper roof is $8 \mathrm{~m}$, and the plastic zone in the shallow roof and floor is dominated by tensile failure and the two sides and other deep areas by shear failure. It indicates that the deformation and failure of the surrounding rock of the rubber-tire haulage gateway are also serious. At the same time, the plastic zone in the two sides of the auxiliary haulage gateway is affected by the vertical stress, and the influence range is more than $8 \mathrm{~m}$. The influence range in the roof and floor is more than $5 \mathrm{~m}$.

As shown in Figure 8(b), due to the existence of hydraulic fractures, the plastic zone in the upper part of the mined roof is fully developed and the roof subsidence is sufficient. The plastic zone on the side of the rubber-tire haulage gateway changes obviously. The plastic zone of the $20 \mathrm{~m}$ coal pillar is less than $5 \mathrm{~m}$, and the plastic zone of the roof is reduced by about $50 \%$, which greatly reduces the deformation and failure of the roof and coal wall. The plastic zone of the two sides of the auxiliary haulage gateway is reduced to less than $4 \mathrm{~m}$, and the development range of the roof and floor is less than $4 \mathrm{~m}$. Compared with the nonhydraulic fracturing section, the reduction of plastic zone is obvious in the hydraulic fracturing section. It indicates that hydraulic fracturing is more conducive to reducing the mining influence and roadway deformation and maintaining the stability of the roadway.

(3) Influence of Hydraulic Fracturing Pressure Relief on the Deformation of Surrounding Rock. Figure 9 shows the distribution of displacement and deformation curve of rubbertire haulage gateway 14203 in the two schemes. Through the comparison, it can be seen that the displacement of surrounding rock of roadway in hydraulic fracturing section decreases significantly, with an overall decrease of about $45.8 \%$. The floor and the left and right sides have the most prominent decrease. The left side decreases from about $435 \mathrm{~mm}$ to about $377 \mathrm{~mm}$, and the right side decreases from about $434 \mathrm{~mm}$ to about $174 \mathrm{~mm}$. The change of floor is the biggest, and the decrease is about $365 \mathrm{~mm}$ before and after hydraulic fracturing. The displacement of surrounding rock decreases obviously, which is positively correlated with the plastic zone distribution of surrounding rock. It shows that hydraulic fracturing technology reduces the influence of mining on roadway deformation and maintains the stability of the roadway.

\section{Engineering Practice}

4.1. Hydraulic Fracturing Parameter Design. To ensure the normal production of the working face, the drilling was carried out at the position of rubber-tire haulage gateway 14203, which was $120 \mathrm{~m}$ away from the working face. Figure 10 shows the hydraulic fracturing parameters and roadway support parameters of the rubber-tire haulage gateway in the working face 14203. The construction sequence was as follows: observation of roof rock structure with a peep scope $\longrightarrow$ in situ test of roof rock strength $\longrightarrow$ determination of fracturing parameters $\longrightarrow$ fracturing drilling operation $\longrightarrow$ implementation of fracturing $\longrightarrow$ fracturing monitoring. The underground construction started on July 20, 2019, and ended on January 20, 2020. The length of the test roadway in the working face 14203 was $300 \mathrm{~m}$, and a total of 60 boreholes were constructed:

(1) The fracturing boreholes were arranged along the axial direction of the haulage gateway. The opening position was about $1 \mathrm{~m}$ away from the coal pillar, and the included angles with the roadway were $45^{\circ}$ and $5^{\circ}$, respectively, as shown in Figures 10(a) and 10(b). The actual angle and opening position were adjusted according to the field space.

(2) The length of boreholes was $50 \mathrm{~m}$, the dip angle was $50^{\circ}$, and the spacing was $10 \mathrm{~m}$, as shown in Figure 10(c).

(3) Roadway support parameters: two corners of the roadway roof were supported by the $\varnothing 21.98 \mathrm{~mm} \times$ $4300 \mathrm{~mm}(1 \times 19)$ anchor cables. The dip angle of anchor cables was $15^{\circ}$, the preload was more than $200 \mathrm{kN}$, and the row spacing between anchor cables 


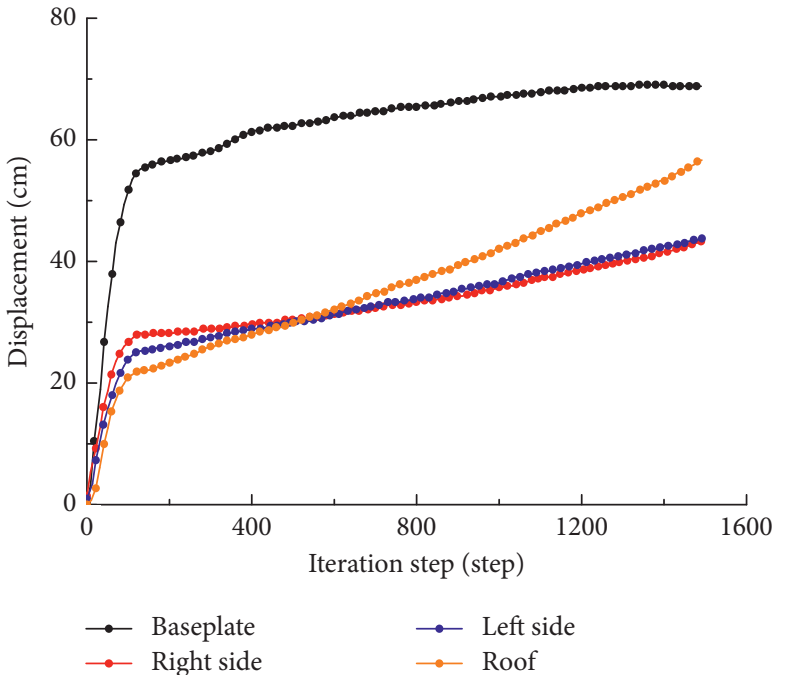

(a)

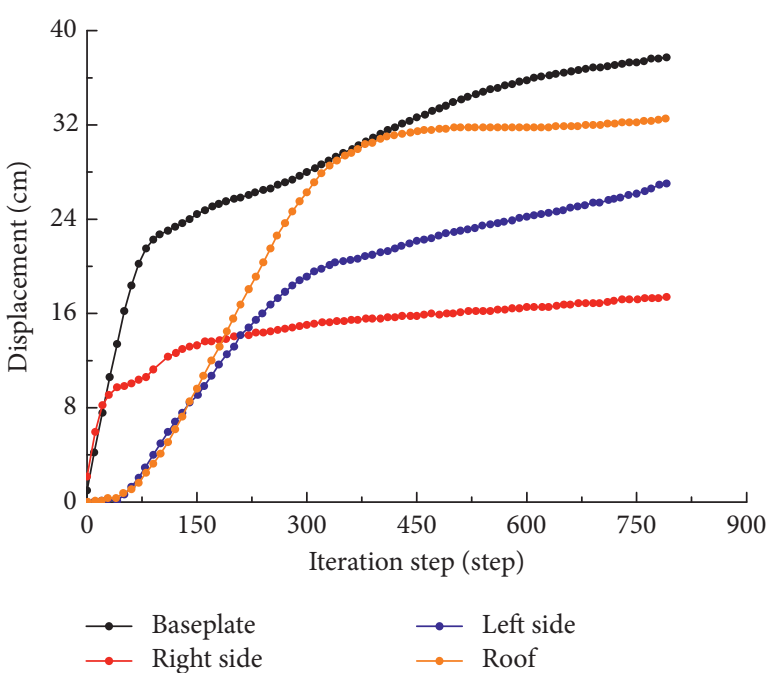

(b)

FiguRE 9: Displacement curve distribution of rubber-tire haulage gateway 14203 in two schemes. (a) Nonhydraulic fracturing. (b) Hydraulic fracturing.

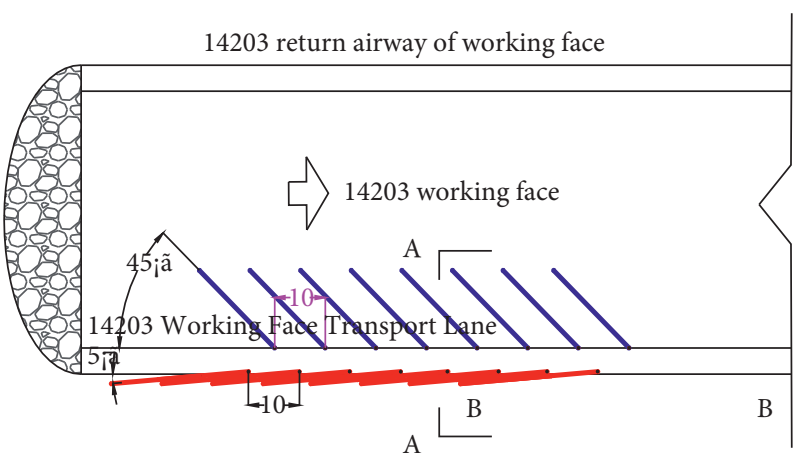

(a)

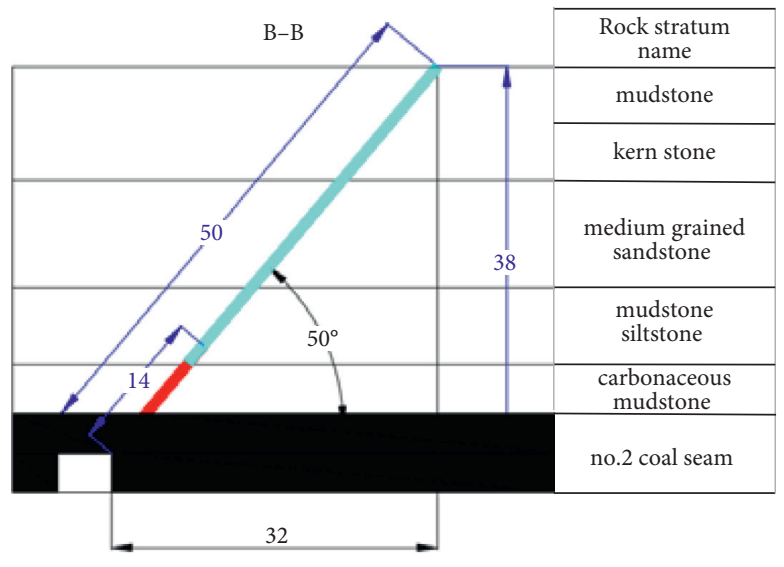

(c)

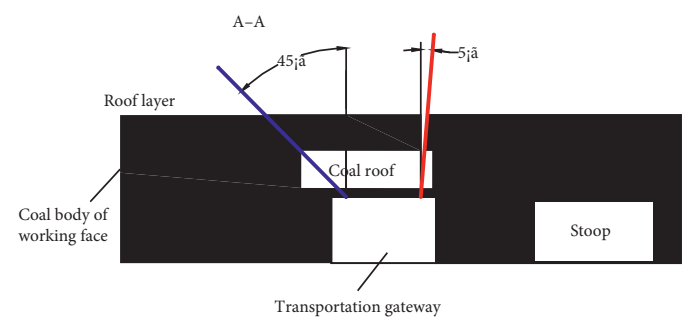

(b)

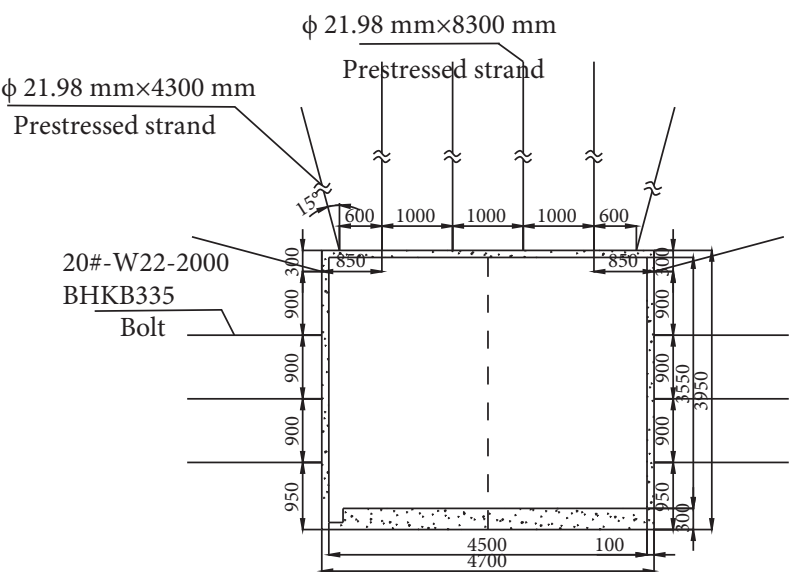

(d)

Figure 10: Hydraulic fracturing and supporting parameters of rubber haulage gateway 14203. (a) Drilling layout plan. (b) Section A-A. (c) Section B-B. (d) Sectional view of rubber-tire haulage gateway support.

was $1000 / 600 \times 900 \mathrm{~mm}$. The top of the cable truss was arranged for support, the specification of this cable was $21.98 \mathrm{~mm} \times 8300 \mathrm{~mm}$, and the cable preload was greater than $200 \mathrm{kN}$. The anchor cable trusses $L=3800 \mathrm{~mm}$ were arranged symmetrically along both sides of the center line, and the row 
spacing was $900 \mathrm{~mm}$. The W $280 \times 5 \times 4700-1000 /$ 600-6 type W steel strip was used for the top support. The $\varphi 6.5 \mathrm{~mm}$ round steel welded steel mesh was hung at the top of the roadway, and the mesh size was $100 \times 100 \mathrm{~mm}$. The 20\#-M22-2000 BHRB335 lefthanded rebar bolt without longitudinal bar was adopted at the side of the roadway. The tensile force of the bolt at the side was greater than $50 \mathrm{kN}$, the row spacing between the bolts was $900 \times 900 \mathrm{~mm}$, and the spray layer with a thickness of $400 \mathrm{~mm}$ was laid on the bottom plate, as shown in Figure 10(d).

4.2. Monitoring Content and Scheme. In the working face 14203, three measuring stations were respectively arranged in the hydraulic fracturing section and nonhydraulic fracturing section, with a total of six measuring stations. The interval of stations was $100 \mathrm{~m}$, as shown in Figure 11. The hydraulic fracturing section was $120 \mathrm{~m}$ away from the working face. The surface displacement of the roadway, roof separation, and anchor cable stress were mainly monitored.

4.3. Engineering Effect. The monitoring results of 5\# station in the nonhydraulic fracturing section and $2 \#$ station in the hydraulic fracturing section of the rubber-tire haulage gateway in the working face 14203 were compared and analyzed.

4.3.1. Roadway Surface Displacement. According to the monitoring results of $5 \#$ station and $2 \#$ station, the roadway surface displacements of nonhydraulic fracturing section and hydraulic fracturing section in the working face 14203 are plotted respectively, as shown in Figures 12 and 13. The maximum roof subsidence of the nonhydraulic fracturing section is $310 \mathrm{~mm}$, the maximum floor heave is $760 \mathrm{~mm}$, the maximum displacement of the left side is $607 \mathrm{~mm}$, and the maximum displacement of the right side is $409 \mathrm{~mm}$. When the hydraulic fracturing section is $110 \mathrm{~m}$ away from the working face, the surrounding rock of the roadway has obvious displacement changes. When it is $80 \mathrm{~m}$ away from the working face, the displacement of surrounding rock rapidly increases. However, compared with the nonhydraulic fracturing section, the roof subsidence, floor heave, left side, and right side of the hydraulic fracturing section decrease by $52.2 \%, 53.8 \%, 59.2 \%$, and $44.5 \%$, respectively. At the same time, when the hydraulic fracturing section is $90 \mathrm{~m}$ away from the working face, the displacement of the surrounding rock of the roadway changes; when it is $80 \mathrm{~m}$ away from the working face, the displacement of surrounding rock of roadway increases rapidly. Therefore, hydraulic fracturing has an obvious effect on the roadway stability control.

4.3.2. Roof and Floor Separation of Roadway. The separation amount of roof and floor in the roadway is also the rock movement amount at the roof and floor of the roadway. According to the monitoring results of $5 \#$ station and 2\# station, the roof and floor separation of nonhydraulic fracturing section and hydraulic fracturing section in working face 14203 are drawn, as shown in Figures 14 and 15. When the distance from the working face is $130 \mathrm{~m}$, the roof separation of roadway occurs in the nonhydraulic fracturing section (monitored by $5 \#$ station), which is consistent with the response of roof subsidence. It indicates that the separation and roof subsidence have a positive correlation. When the distance from the working face is $60 \mathrm{~m}$, the amount of roof separation begins to increase rapidly. When the distance from the working face is $0 \mathrm{~m}$, the maximum value of the deep base point is $186 \mathrm{~mm}$, and the maximum value of the shallow base point is $68 \mathrm{~mm}$. However, in the hydraulic fracturing section, when the distance is $100 \mathrm{~m}$ away from the working face, the roof separation occurs (monitored by $2 \#$ station). When the distance from the working face is $65 \mathrm{~m}$, the amount of roof separation is significant. When the distance from the working face is $0 \mathrm{~m}$, the maximum values are obtained. The maximum value of the deep base point is $164.7 \mathrm{~mm}$, and that of the shallow base point is $22 \mathrm{~mm}$ in the hydraulic fracturing section, which is $22.6 \%$ and $60 \%$ less than that of the nonhydraulic fracturing section. The amount of roof separation presents the characteristics of decreasing from deep to shallow.

\subsubsection{Bolt Stress}

(1) Stress Analysis of Side Bolt of Coal Pillar. Figures 16 and 17 show the stress curves of the bolts at the coal pillar side of $5 \#$ and $2 \#$ stations, respectively. It can be seen that the stress of the upper $2 \#$ bolt in the nonhydraulic fracturing section is less than that of the lower $1 \#$ bolt, and the stress of the two bolts shows a gradually increasing trend. This suggests that the lower bolt is obviously affected by the floor heave, and the stress is obviously larger. With the advance of the working face, the stress of the bolt increases gradually. When the distance from the working face is $0 \mathrm{~m}$, the stress of the upper 2 \# bolt reaches the maximum value of $163.8 \mathrm{kN}$, and the stress of the lower 1 \# bolt increases to $105.3 \mathrm{kN}$ and does not change. When the distance is $100 \mathrm{~m}$ away from the working face in the hydraulic fracturing section, the bolt stress on the side of the coal pillar begins to increase, in which 2 \# bolt increases more rapidly than the lower $1 \#$. It indicates that the pressure on the upper part of the coal pillar is faster. When it is $65 \mathrm{~m}$ away from the working face, the stress of the upper 2\# bolt reaches the maximum value of $112 \mathrm{kN}$ and suddenly decreases to $0 \mathrm{kN}$. The actual observation shows that the bolt tail breaks off. The stress of the lower $1 \#$ bolt increases continuously until it reaches $85 \mathrm{kN}$ and does not change. Compared with the nonhydraulic fracturing section, the stress of the side bolt of the coal pillar in the hydraulic fracturing section is reduced by $12.3 \%-31.9 \%$ on average.

(2) Stress Analysis of Side Bolt in the Mining Face. Figures 18 and 19 show the stress curves of the bolts at the mining face of $5 \#$ and $2 \#$ stations, respectively. As shown in Figure 18, the stress of $3 \#$ bolt in the nonhydraulic fracturing section decreases slowly at the later stage, while the stress of the lower $4 \#$ bolt increases greatly at the later 


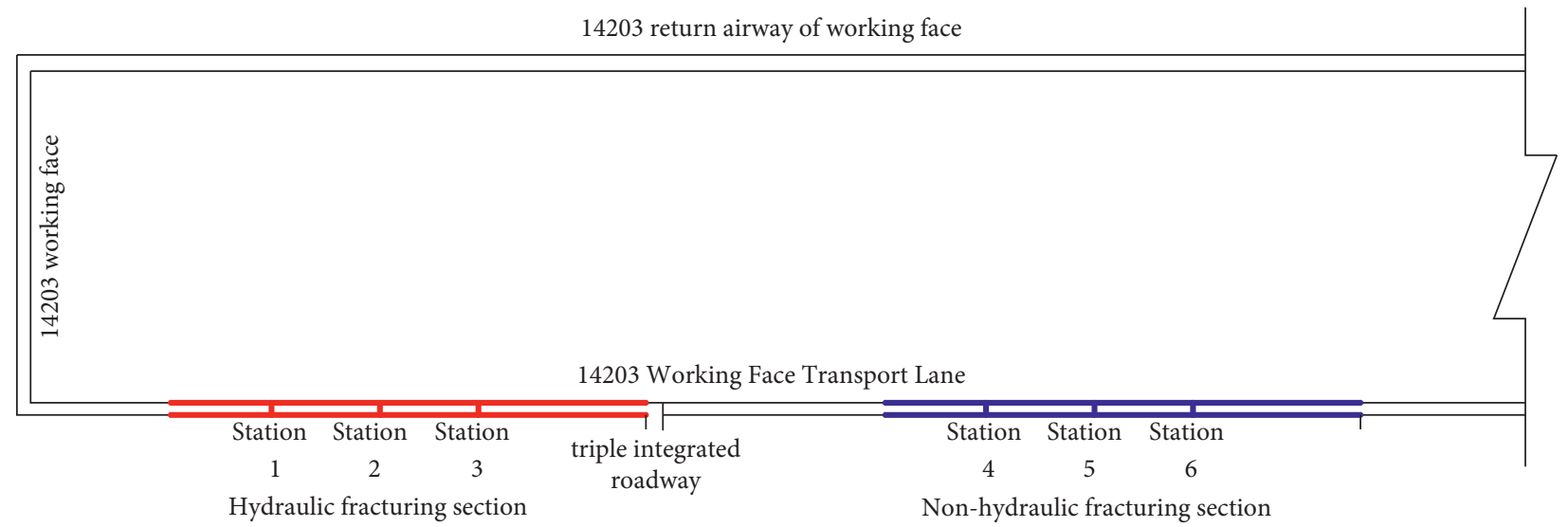

FIGURE 11: Hydraulic fracturing parameters of rubber haulage gateway 14203.

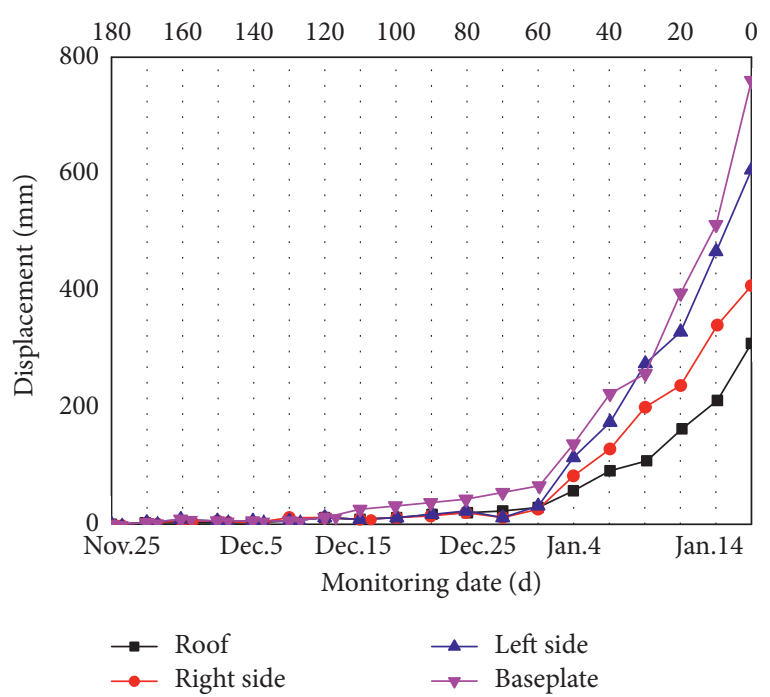

FIgURE 12: Nonhydraulic fracturing section: displacement variation of surrounding rock monitored by $5 \#$ station.

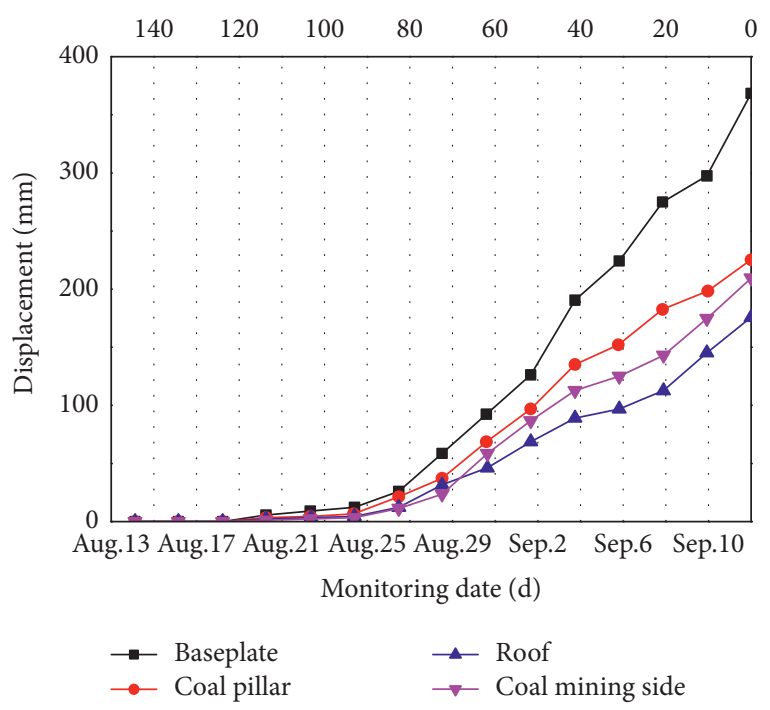

FIGURE 13: Hydraulic fracturing section: displacement variation of surrounding rock monitored by $2 \#$ station.

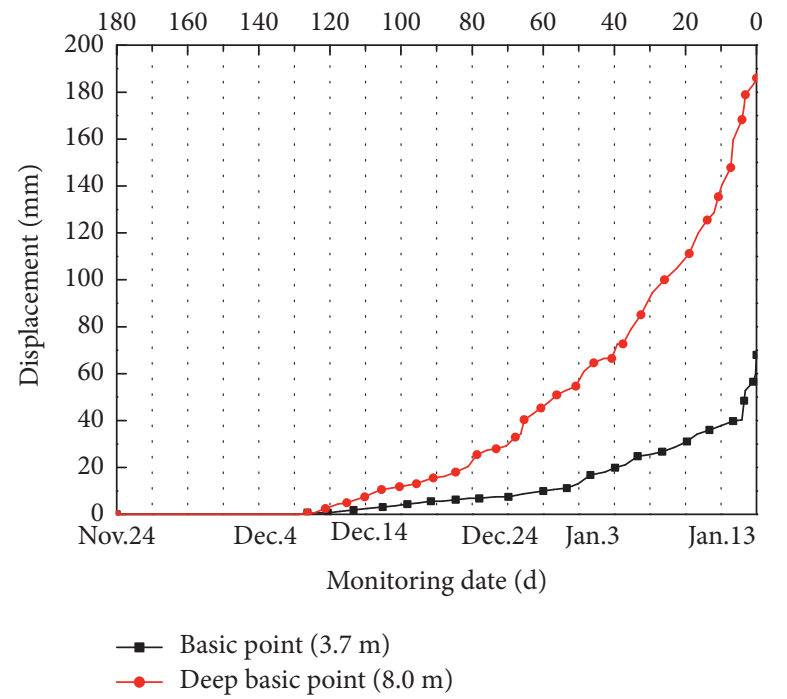

FIgURE 14: Nonhydraulic fracturing section: roof separation curve of $5 \#$ station.

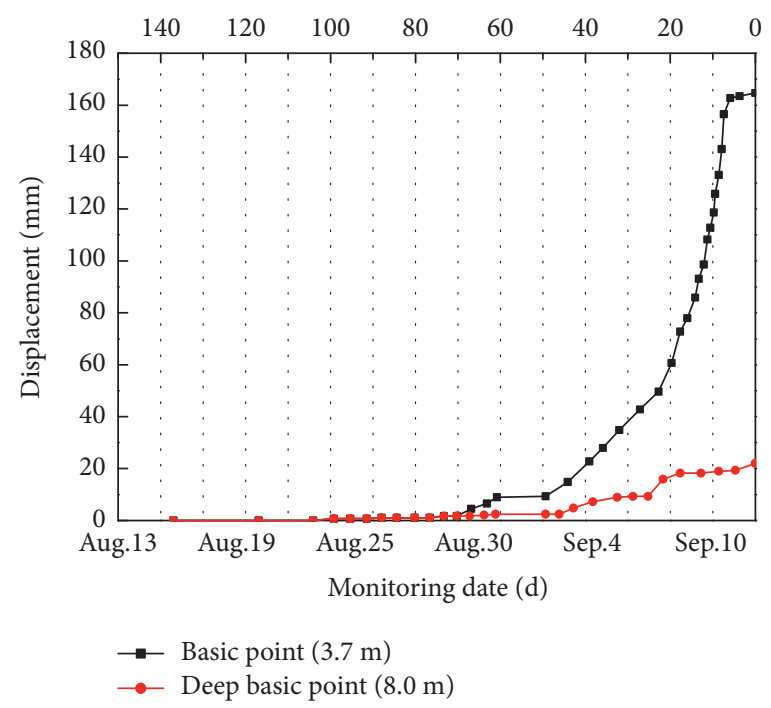

FIgURE 15: Hydraulic fracturing section: roof separation curve of 2\# station. 


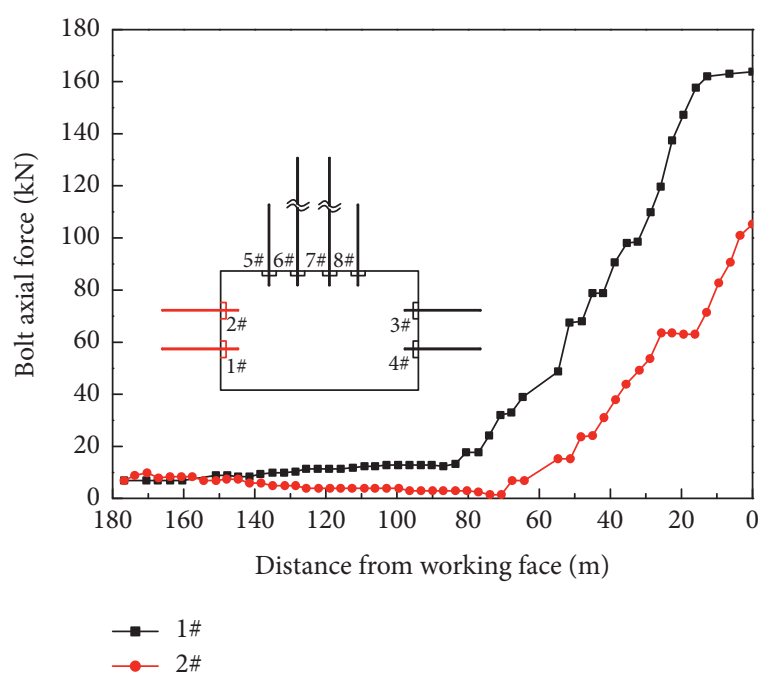

FIGURE 16: Nonhydraulic fracturing section: stress of side bolt of coal pillar at $5 \#$ station.

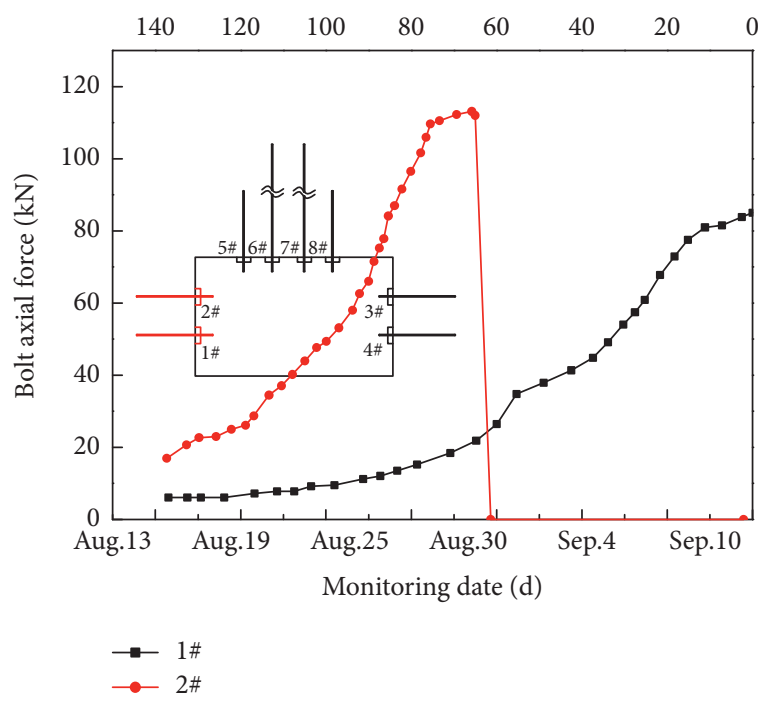

Figure 17: Hydraulic fracturing section: stress of side bolt of coal pillar at 2\# station.

stage. When the distance from the working face is $30 \mathrm{~m}$, the stress of the upper $3 \#$ bolt reaches the maximum value of $84 \mathrm{kN}$, and the stress drops sharply to 0 , and the stress of the lower 4 \# bolt begins to rise rapidly. When the distance from the working face is $0 \mathrm{~m}$, the stress of the lower 4 \# bolt reaches $136 \mathrm{kN}$. As shown in Figure 19, the supporting force of $3 \#$ bolt in the hydraulic fracturing section fluctuates strongly in the later stage, while that of $4 \#$ bolt increases steadily. When it is $15 \mathrm{~m}$ away from the working face, the maximum stress of the upper $3 \#$ and lower $4 \#$ bolts is $78 \mathrm{kN}$ and $42 \mathrm{kN}$. Then the stress of the upper $3 \#$ bolt decays. Finally, the upper $3 \#$ bolt is stable at about $57 \mathrm{kN}$, and the lower 4 \# bolt reaches the maximum value of $46 \mathrm{kN}$. The stress of the side bolt in the hydraulic fracturing section is $56.1 \%-51.8 \%$ less than that in the nonhydraulic fracturing section.

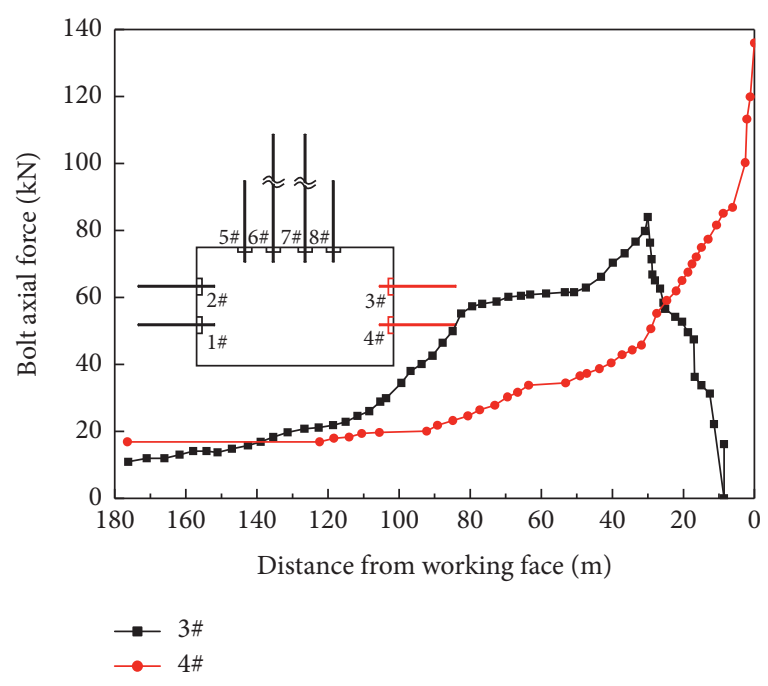

FIgURE 18: Stress of side bolt at $5 \#$ station in the nonhydraulic fracturing section.

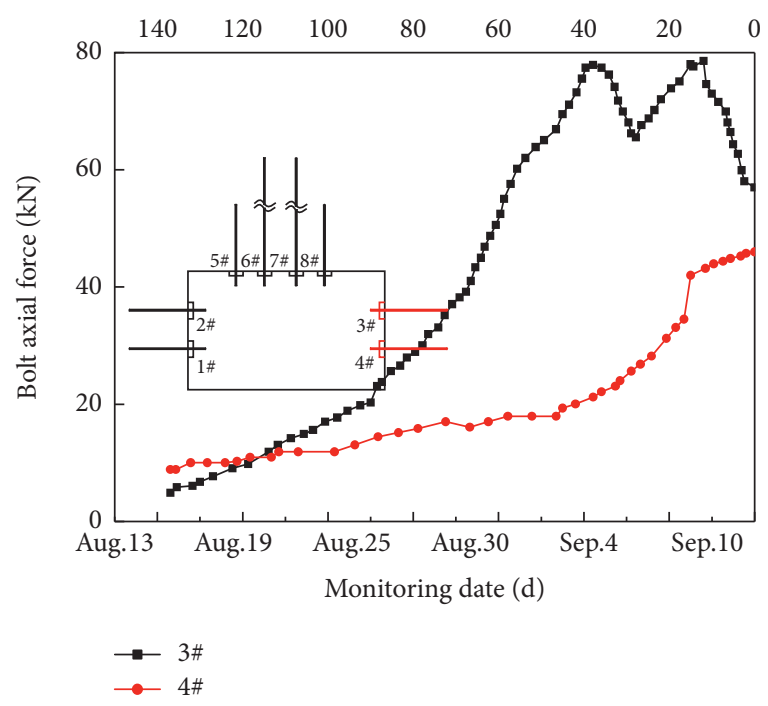

Figure 19: Stress of side bolt at 2\# station in the hydraulic fracturing section.

\subsubsection{Anchor Cable Stress}

(1) Stress Analysis of the Anchor Cable at Coal Pillar Side. Figures 20 and 21 show stress curves of anchor cable at coal pillar side of $5 \#$ and $2 \#$ measuring stations, respectively. As shown in Figure 20, with the advance of the working face, the stress of anchor cable in the nonhydraulic fracturing section increases continuously. When it is $30 \mathrm{~m}$ away from the working face, the stress of anchor cable decreases rapidly. With the decreasing distance to the working face, the stress of anchor cable increases continuously until the distance is about $0 \mathrm{~m}$. The stress of $5 \#$ anchor cable reaches the maximum value of $239 \mathrm{kN}$ and that of $6 \#$ anchor cable reaches more than $500 \mathrm{kN}$. These conditions are consistent with the characteristics of roof subsidence. As shown in Figure 21, when hydraulic fracturing technology is adopted and the distance 


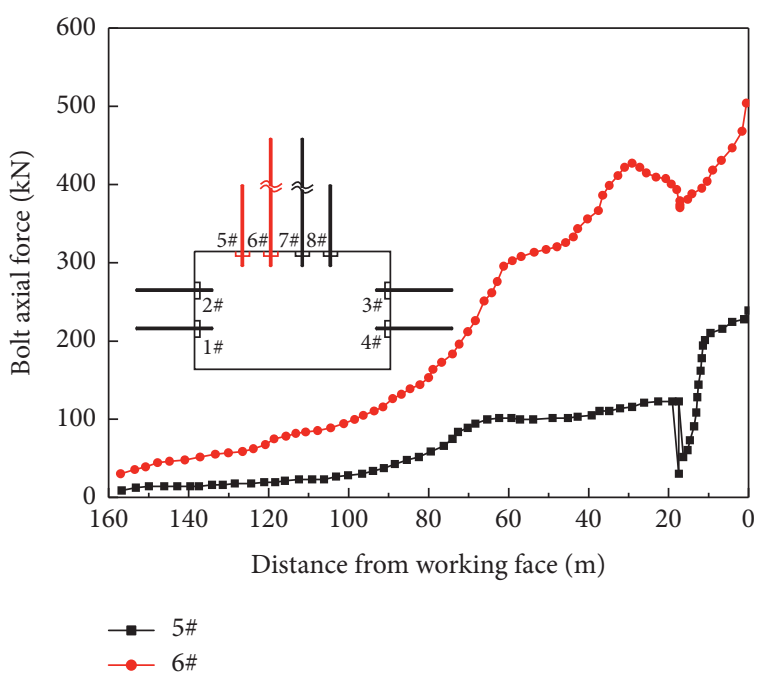

FIGURE 20: Nonhydraulic fracturing section: stress of the anchor cable at coal pillar side of $5 \#$ station.

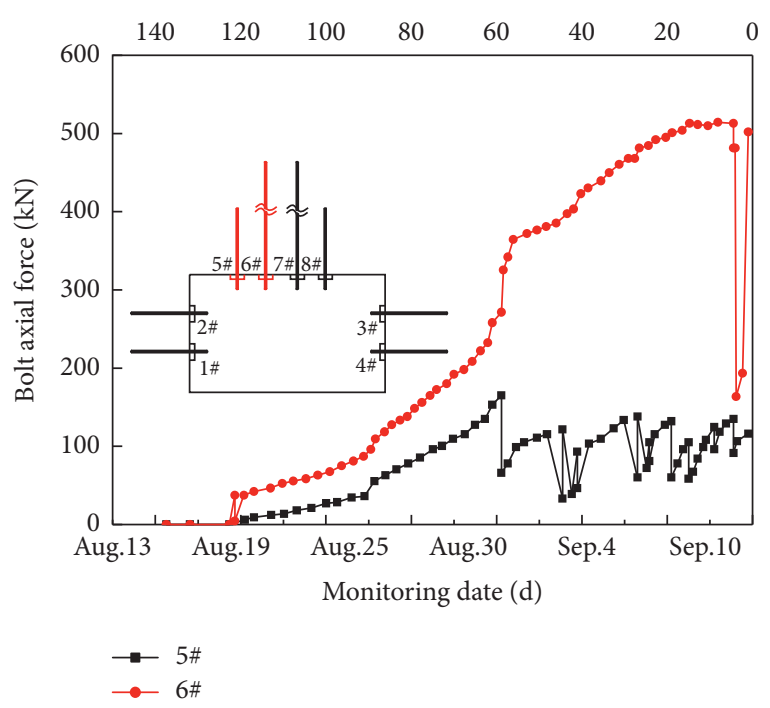

FIGURE 21: Hydraulic fracturing section: stress of the anchor cable at coal pillar side of $2 \#$ station.

from the working face is $60 \mathrm{~m}$, the stress of $6 \#$ and $5 \#$ fluctuates, indicating that the roof failure fluctuates. When the distance is $1 \mathrm{~m}$ away from the working face, the stress reaches the maximum value of $502 \mathrm{kN}$ and $116 \mathrm{kN}$, with an average reduction of $44.8 \%$ and $16.4 \%$.

(2) Stress Analysis of the Side Anchor Cable in Mining Face. Figures 22 and 23 show the stress curves of the anchor cable at the mining face of $5 \#$ and $2 \#$ measuring stations, respectively. As shown in Figure 22, for the nonhydraulic fracturing section, when the distance is $100 \mathrm{~m}$ away from the working face, the stress of the anchor cable begins to increase, which synchronizes with the increase of roof subsidence and separation amount. With the advance of the working face, the stress of the anchor cable continues to increase until the distance is $0 \mathrm{~m}$ away from the working

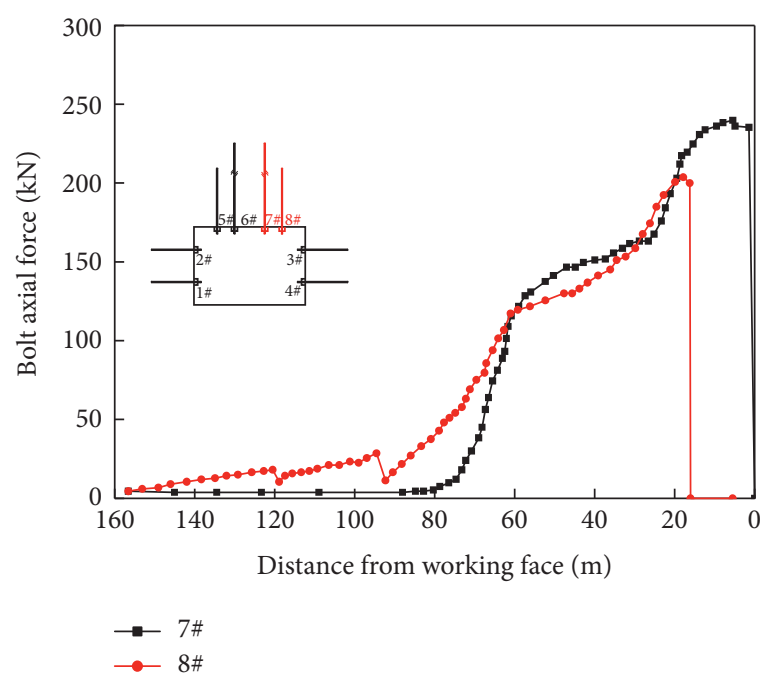

FIgURE 22: Nonhydraulic fracturing section: stress of the anchor cable at $5 \#$ station.

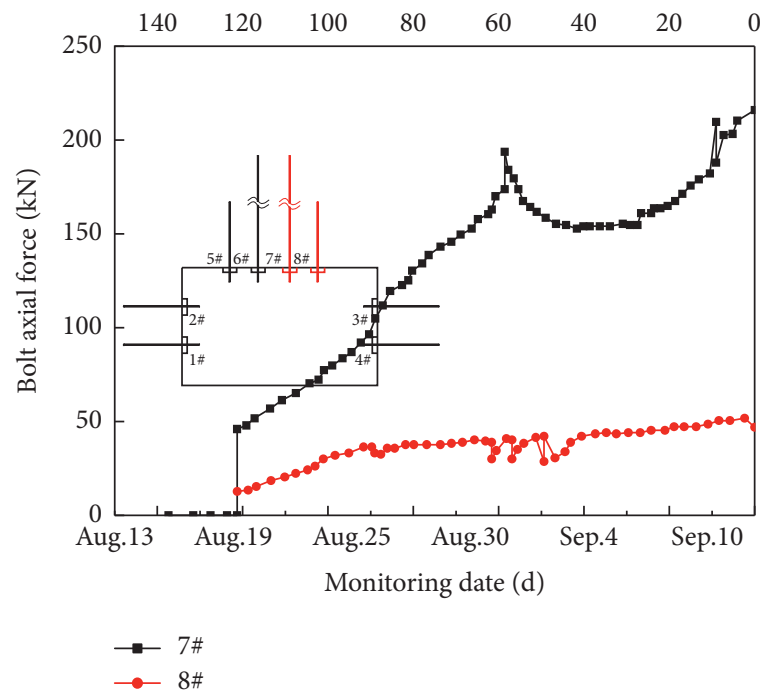

FIGURE 23: Hydraulic fracturing section: stress of the anchor cable at $2 \#$ station.

face and then the stress remains relatively stable. The stress of the outer 8 \# anchor cable is $205 \mathrm{kN}$ and the inner 7 \# anchor cable is $242 \mathrm{kN}$. As shown in Figure 23, for the hydraulic fracturing section, with the advance of the working face, the stress of the anchor cable increases and remains stable until the distance is $10 \mathrm{~m}$ away from the working face. The stress of the 7 \# anchor cable is $216 \mathrm{kN}$ and that of the 8 \# anchor cable is $47 \mathrm{kN}$. Compared with the nonhydraulic fracturing section, the stress of anchor cable is reduced by $48 \%$ and $51.3 \%$ on average in the hydraulic fracturing section.

\section{Conclusion}

(1) On the premise of not destroying the stability of roadway in working face, the fracture position of the roof can be artificially controlled, and the high-stress 
from the lateral cantilever beam of the working face to the coal pillar of the retained roadway can be unloaded or transferred to improve the stress state of the retained roadway.

(2) Hydraulic fracturing pressure relief technology changes the deformation and failure mode of roof and restricts the development of the plastic zone of surrounding rock in the roadway. As a result, the deformation and failure of roof and coal sides are greatly alleviated, and the stress of anchor bolt and anchor cable is reduced to varying degrees.

\section{Data Availability}

The data in this paper were obtained by field measurement and laboratory test.

\section{Conflicts of Interest}

The authors declare no conflicts of interest.

\section{Authors' Contributions}

Formal analysis was carried out by P. Z. and X. M.; funding acquisition was made by N. L.; investigation was conducted by Y. G.; methodology was employed by Y. J. and K. M.; the original draft was written by W. Z.; reviewing and editing were done by W. Z. All authors have read and agreed on the published version of the manuscript.

\section{Acknowledgments}

This work was supported by the National Natural Science Foundation of China (Nos. 52104103, 52174128, and 51774269), the Natural Science Foundation of Jiangsu Province (Nos. BK20210499 and BK20190031), National Science Fund for Excellent Young Scholars (No. 52022107), and the China Postdoctoral Science Foundation (No. 2020M681771).

\section{References}

[1] J. B. Bai and C. J. Hou, "Control principle of surrounding rocks in deep roadway and its application," Journal of China University of Mining \& Technology, vol. 35, no. 2, pp. 145-148, 2006.

[2] L. Yuan, J. H. Xue, Q. S. Liu, and B. Liu, "Surrounding rock stability control theory and support technique in deep rock roadway for coal mine," Journal of the China Coal Society, vol. 36, no. 4, pp. 535-543, 2011.

[3] T. Xiao, X. Wang, and Z. Zhang, "Stability control of surrounding rocks for a coal roadway in a deep tectonic region," International Journal of Mining Science and Technology, vol. 24, no. 2, pp. 171-176, 2014.

[4] J. Chang and G. Xie, "Research on space-time coupling action laws of anchor-cable strengthening supporting for rock roadway in deep coal mine," Journal of Coal Science and Engineering, vol. 18, no. 2, pp. 113-117, 2012.

[5] D. S. Kong and Y. P. Chen, "Stability pediction of surrounding rocks and optimum design of roof-bolt parameters in deep roadway," Applied Mechanics and Materials, vol. 353-356, pp. 436-439, 2013.

[6] X. Y. Zhang, "Pressure releasing technology with borehole drilling and blasting for mine roadway in high stressed strata," Coal Science and Technology, vol. 37, pp. 74-77, 2009.

[7] X. Yang, C. Hu, M. He et al., "Study on presplitting blasting the roof strata of adjacent roadway to control roadway deformation," Shock and Vibration, vol. 2019, Article ID 3174898, 16 pages, 2019.

[8] S. Yang, M. He, W. Liu, and X. Ma, "Mechanics and application research on the floor anchor to control the floor heave of deep soft rock roadway," Chinese Journal of Rock Mechanics and Engineering, vol. 27, pp. 2913-2920, 2008.

[9] M. C. He, G. Qi, C. Cheng, Z. Guofeng, and S. Xiaoming, "Deformation and damage mechanisms and coupling support design in deep coal roadway with compound roof," Journal of Rock Mechanics and Engineering, vol. 26, no. 5, pp. 987-993, 2007, in Chinese.

[10] X. M. Sun, M. C. He, and X. J. Yang, "Study on nonlinear design method of coupling support of anchor, mesh and cable in deep soft rock roadway," Rock and Soil Mechanics, vol. 27, no. 7, pp. 1061-1065, 2006, in Chinese.

[11] J. Zuo, J. Wang, and Y. Jiang, "Macro/meso failure behavior of surrounding rock in deep roadway and its control technology," International Journal of Coal Science \& Technology, vol. 6, no. 3, pp. 301-319, 2019.

[12] Z. Xiao, J. Liu, S. Gu et al., "A control method of rock burst for dynamic roadway floor in deep mining mine," Shock and Vibration, vol. 2019, Article ID 7938491, 16 pages, 2019.

[13] Y. D. Wei, L. H. Chen, X. U. Chang-Yu, and J. H. Liu, "Mechanism and application of coupling grouting reinforcement for crossing of deep soft rock roadway," Value Engineering, vol. 38, no. 4, pp. 133-136, 2019, in Chinese.

[14] X. Guo and D. Hao, "Deformation characteristics of surrounding rock of deep soft rock roadway and mechanism of full anchor cable supporting," China Mining Magazine, vol. 28, no. 12, pp. 123-127, 2019, in Chinese.

[15] W. Liu, X. Zhang, and C. Huang, "Surrounding rock supporting technology in deep roadway of xingdong coal mine," Safety In Coal Mines, vol. 50, no. 6, pp. 86-90, 2019.

[16] T. Z. Zhang and C. Company, "Research and application of floor heave collaborative control technology in deep mine high stress coal-winning roadway," Coal Science \& Technology Magazine, vol. 40, no. 3, pp. 54-57, 2019, in Chinese.

[17] J. Han, "Analysis on pressure relief process of coal mine hydraulic fracturing," Energy and Energy Conservation, no. 12, pp. 102-103, 2019, in Chinese.

[18] C. Zhai, M. Li, C. Sun, J. Zhang, W. Yang, and Q. Li, "Guidingcontrolling technology of coal seam hydraulic fracturing fractures extension," International Journal of Mining Science \& Technology, vol. 22, no. 6, pp. 831-836, 2012.

[19] J. Zhao and G. Li, "Pressure-relief mining of the working face under the coal pillar in the close distance coal seams," Geotechnical \& Geological Engineering, vol. 34, no. 4, pp. 10671077, 2016.

[20] J. Guo, "Application of hydraulic fracturing and cutting top pressure relief technology in the roadway along the goaf," Coal and Chemical Industry, vol. 3, pp. 47-49, 2019.

[21] Y. Li, "Study on hydraulic fracturing roof cutting and pressure relief technology of removal channel in fully mechanized caving face," Datong Coal Science \& Technology, no. 4, pp. 21-23, 2019, in Chinese. 